\title{
New Insights on Slavic god Volosъ/ Velesb from a Vedic Perspective
}

\section{Milorad Ivanković}

In 1973, Ivanov and Toporov developed an attempted reconstruction of the presumably central theme of ancient Slavic mythology, viz. the cosmic battle between the thunder-god Perunb and his adversary Voloss the cattle god, modelled after the analogous examples taken from Baltic folklore and Vedic mythology, whereby the Slavic god Volosb was identified with the Vedic demon, Vala. On the same footing, in 2008, came Katičić with similar results, but he identified the Slavic god Volosb with the Vedic demon Vrtra. However, the evidence from the primary Vedic and Sanskrit sources presented in this treatise soundly disproves the above interpretations and identifications and reveals quite a different image of the Slavic god.

KEYWORDS: Volosъ, oath, waters, wool, world-tree, Vala, Vrtra, Varuṇa

\section{METHODOLOGY}

Unlike the attempted reconstructions by Ivanov and Toporov (1973) and Katičić (2008), which were founded mostly on conjecture, the comparative method utilized in this treatise relies on a strict comparative analysis of facts gathered from:

1. Authentic Vedic and Sanskrit texts

2. Data on the Slavic god from historical documents

3. Data on the Slavic god from South Slavic folk-poems

4. Data on the Slavic god from South Slavic folk-tales

5. Some data on Old Slavic funerals from the writings of a medieval Arabic traveller

6. Some pertinent accounts on Volosъ's Baltic correlatives from Lithuanian and Latvian folklore.

Presented are the crucial aspects, features, and functions of the Slavic god in parallel with the fully congruent examples from the Indo-Aryan and Baltic mythology.

\section{GOD OF OATHS, CONTRACTS, AND PEACE AGREEMENTS}

The name of the Slavic god Volosz (Velesz) appears in some historical documents. According to records found in the Old Russian Chronicles, King Oleg made a peace agreement 
with a Byzantine Emperor in the year 907; likewise, King Igor repeated it in the year 971, by swearing an oath in the names of gods Perunb and Voloss "the cattle god" (Jakobson 1969/1985: 33). Undoubtedly, Volosb was venerated in antiquity together with Peruns the thunder-god, as the supreme god of the Slavs, since they always appear together as a complementary pair (not as adversaries). Therefore, he could not have authentically been a demon. This is confirmed by the fact that Volosb is recorded in the documents literally as bogz viz. 'god', not as demon viz. běs (Jakobson 1969: 34). Thus, the Slavic god Volosb/Velesb appears to be the epitome of Social Order, viz. the one who guaranteed the fulfilment of social obligations (such as oaths, contracts, and agreements), and not a representative of nered viz. "disorder" (as assumed by Katičić, 2008: 144, 193).

There are also accounts on "civil" usages of oaths by the Russian non-Christianized folk in the city of Yaroslavl, who bonded themselves in the name of god Volosb, as the subjects of their Christianized ruler to pay tributes and serve him faithfully (Katičić: 2008, 127).

On the Vedic side, neither Vala nor Vrtra, but the sovereign god Varuna is the one who performed the same function among the Vedic divinities, as is attested in the Mitanni-Hittite treaty of c. 1400 BCE sworn by the names of the gods Mitra, Varuna, and Indra as the guarantors of the agreement on the part of the Mitanni (cf. Fournet: 2010: 36).

There were other occasions, like religious rites, during which the Vedic sacrificers used to swear by Varuṇa, e.g., Śatapatha Brāhmaṇa, III 8.5.:

Verse 10. dhắmnodhāmno rājaṃstáto varuna no muñca yádāhúraghnyā íti várunéti śápāmahe táto varuṇa no muñcéti tádenaṃ sárvasmādvaruṇapāsaātsárvasmādvarunyātprámuñcati

(From every precept - therefrom set us free, O king Varuna. That they say, we swear by the "Holy ones [a-ghnyāh, literally not-to-be-killed, in-violable, viz. Cows]", by Varuna, therefrom set us free, O Varuna!' Thereby he sets him free from every noose of Varuna, from every [sc. sin] against Varuna.)

And Śatapatha Brāhmaṇa, XII 9.2. (utilized during the ávabhrotha viz. sacrificial bath):

Verse 4. yád ăpo aghnyă íti varunéti śápāmahe táto varuṇa no muñcéti varuṇyàd evaìnam énaso muñcaty.

(That we swear by the Holy [a-ghnyāh as above, here attributed to] Waters, by Varuna, therefrom set us free, O Varuna!' - he thereby sets him free from sin against Varuna.)

As Jakobson keenly observed: Both Slavic Volosb and Vedic Varuna act as the guarantors of right and guarantors of human treaties who severely punish the infringement of vows by afflicting the violators with a disease (Jakobson, ibid.: 41). However, the etymology of Veless and Varuna proposed by him as derived from *vel "to see" (Jakobson, ibid.: 40) is unlikely, since the root is unknown to Indo-Iranian and his name is more convincingly explained, as the Vedic poets and commentators understood it, from var(-u-) "to cover, protect"'(West 2007: 146).

The Russian-Byzantine treaty of $971 \mathrm{CE}$ specifies a menacing punishment by Volosb to the violators of the oath in the form of a disease formulated da budems zoloti jako zoloto viz. "may we become golden as gold", viz. jaundice (Jakobson 1969: 35, 38).

As for Varuna, he himself bears the epithet hari "gold-hued, golden" (Atharva-Veda $\mathrm{V}$ 11.1) and is imagined by the Vedic ritualists (see quotations from the Brāhmanas 
further below) in a quite similar form, viz. as "a bald-headed man with yellow-eyes" (cf. also Jakobson ibid.: 38). Varuna is said to have inflicted a disease described as dŕtir na dhmātó viz. "swollen like a water bag" denoting oedema or dropsy (an excess of water in the tissue), on Vasișțha the seer of the hymn (Rig-Veda VII 89.1-2), due to his moral weakness. A sick person and sinner is also considered Varuna-grhita "seized by Varuna" (Kāthaka Samhitā X 4). And certainly when the an-rta viz. "dis-order, in-justice, un-rightness" is being done ánrte khálu vái kriyámāṇe Varuṇa seizes váruṇo gronṇāti (Taittirīya Brāhmana I 7.2.6). Accordingly, Varuṇa indeed is considered the "injurer", váruṇo vắ ārpayitā (Śatapatha Brāhmana IV 5.7.7).

NB. There is not a single piece of evidence adduced by Ivanov, Toporov, and Katičić from Aryan history that anyone ever used to swear by the demons Vala or Vrtra or invoke them as the guarantors of oaths, contracts, and peace agreements. Therefore, they apparently never shared this function with Slavic Volosb and Vedic Varuna. ${ }^{1}$

\section{ASSOCIATED WITH POETRY AND WISDOM}

Veleş too, like Varuna, is associated with poetry and wisdom. In the Old Russian epic Slovo o plıku Igorevě, ("The Lay of Igor") the legendary seer Bojan is called "the grandson of Veles" (Jakobson, ibid: 36). Though some other Vedic god may have been, like Varuna, considered kavitama "the best poet" (Rig-Veda V 85.6), Varuna alone is exclusively described as yásmin víśvāni kăvyā cakré näbhiriva śrită viz. "the one in whom all Poetry is focused like a nave within a wheel" (Rig-Veda VIII 41.6). Varuṇa with his power made Vasistha a rși viz. "seer" (Rig-Veda VII 88.4). In South Slavic folk-tales, Velesb appears as a wise old man named Velimir, a compound meaning "great, famous $(-$ mir < *mēros, cf. Skok 1972: 446) in speech (Veli-< velěti to speak) and counselling”. Varuṇa likewise is designated vidvăn "one who knows" (Rig-Veda I 24.13), prácetas "attentive, observant, mindful, clever" (ibid. verse 14), and medhira "wise" (Rig-Veda I 25.20) and is explicitly associated with medha "wisdom" (Atharva-Veda V 11.4).

NB. Significantly, there is no adduced evidence by Ivanov, Toporov and Katičić that Vala and Vrtra were related to either poetry or wisdom.

\section{LORD OF THE WATERS: ASSOCIATED WITH OCEAN/SEA, SHIPS AND WHIRLPOOLS}

Velesъ and Varuna are generally associated with waters, hence with rain, sea, ocean, wells, springs, fountains, swamps, etc. The deep swamps as waters in general, are believed in Lithuanian tradition to be the favourite abode of Vẽlinas [Velnias] who easily rides over marshes inaccessible to human beings (Jakobson 1969: 39).

\footnotetext{
1 It should be admitted, however, that in some of his later articles Toporov parallels Velesz with Varuna (cf. his article titled Varuna In: Mify narodov mira, Toporov 1987: 217-218).
} 
Though Varuna's association with waters is considered by some researchers to be the result of a later development, the adduced quotations (see further below) from the Rig-Veda disproves such assumptions. Hence, Kuiper seems to be perfectly right when he asserts: On the contrary, it must have been the original function of Varuna to represent or impersonate these waters (Kuiper 1979: 27).

Furthermore, Kuiper explains it more elaborately, citing the Rig-Veda VIII 69.12 to justify his view. ${ }^{2}$

Sutherland also argues that In the just and measured regulation of the life-supporting waters, Varuna particularly acquired his reputation as arbiter of cosmic righteousness (Sutherland 1991: 77).

Varuna is Lord of Heaven and of Rain (Rig-Veda V 85.3) viz. viśvasya bhúvanasya râjā "the King over all worlds/beings" yávam ná vrștír vỳunatti bhüma "who waters earth as the rain [waters] the barley".

Varuna is also connected with still (stationary) waters, e.g., Taittirīya Samhitā VI 4.2:

Verse 3. várunagrhītā vái sthāvarăs (All the stationary [sc. waters] are seized by Varuna.)

And Śatapatha Brāhmana IV 4.5.:

Verse 10. ... 'bhyáveyādetā vấ apāṃ váruṇagrhītā yāḥ

(...whatsoever parts of flowing water do not flow, these are seized by Varuna.)

Kuiper further argues that Varuna was also the god of stagnant water because this represents the subterranean waters of Varuna's realm of inertia (Kuiper 1960: 249).

The nether abode of Slavic Velesb is especially connected with watery whirlpools (Katičić, 2011: 117ff, 231-232). Katičić asserts: Velesov dom/dvor je u korijenu svijeta, podzemlju, zemlji bogatih zelenih travnjaka. A u proljeće, kako su pokazali analizirani stari obredni tekstovi, iz tog svijeta dolaze ptice selice. Mjesto iz kojeg dolaze, iz Velesova svijeta, naziva se irij, virij, virj. Taj naziv povezuje se sa značenjem vodeni vrtlog, vir...; (Veles' home is at the root of the world, in the nether world, in the land of green pastures. In spring, migratory birds come from there. And this place is called irij, virij, virj. The term is related to vrtlog, vir, viz. watery whirlpool, vortex, etc.).

As attested by Śatapatha Brāhmana XII 9.2. Varuna too is explicitly associated with the whirlpool, Sanskrit $\bar{a}$-var-ta viz. "a rapidly rotating current of water, a vortex" which is considered Varuna's son or brother:

Verse 4. (continued from above) yó ha vắ ayám apắm ăvartáh sá hắvabhṛtháḥ sá haiṣá váruṇasya putró vă bhrătā.

(The bath, verily, is that whirlpool in the water, and that indeed is Varuna's son or brother.)

\footnotetext{
2 ...before Indra's demiurgic act Varuna and the Asuras were the gods of the primordial world which consisted of the waters. After the emergence of the earth floating on the waters and the subsequent creation of the organized world, the waters were thought of being under the earth as its foundation, as well as surrounding it. Varuna's association with the waters, therefore, is due to the fact that the primeval waters along with their lord Varuna, have been incorporated in the cosmos as part of the nether world. Kuiper further maintains: Hence, it is that Varuna is said to dwell amidst his seven sisters and these seven rivers, when they flow from the central mountain over the earth, are said to emerge from the samudra [ocean] in the nether world through Varuna's throat as trough a hollow reed (Kuiper, 1970: 27).
} 
As is evident from the passages quoted, Vedic ritualists associated the very name Varuna by assonance with Sanskrit $\bar{a}$-var-ta "whirlpool", since it contains the syllable var (related to water, cf. vār "water", vari "streams, rivers", etc.). According to Hillebrandt (1929/1980: 225) in the Rig-Veda II 38.8, the term varuna as an appellative means "fish" only, and the word is connected etymologically with vär "water".

In Czech folklore, Veless in proverbs commonly appears mostly associated with the sea, his abode being nekam k Velesu za moř or nekam Velesu pryč na moře "somewhere to Veles beyond or upon the sea" (Jakobson 1969: 36). Moreover, Jakobson argues that the connection of Varuna with the waters could be associated with the aquatic bent of [Lithuanian] Velinas [sc. Velnias] and with the bond between the sea and Veles in Czech sources (Jakobson ibid.: 41, 42).

Analogously, the samudra viz. "ocean/sea" is specified as the abode of Varuna (Mahābhārata I 19.5, and I 171.24), and full of gambhīra āvartas viz. "deep whirlpools" (ibid. I 19.8).

NB. Note again Varuna's connection with whirlpools.

In the Rig-Veda, Varuna himself is spoken of as veda nāváh "one who knows the ships", and is styled samudríya "pertaining to the ocean/sea" (Rig-Veda I 25.7). Furthermore, Varuṇa is titled jaleśvara, "Lord of the waters" (Mahābhārata II 9.7) and apăm ádhipati "Overlord of the Waters" (Atharva-Veda V 24.4). Incidentally, the identification of Vedic Varuṇa with Avestan/Vedic Apām Napāt as proposed by Boyce (1975: 48) is unfounded, since her proposition also presupposes the identity of the Vedic character of the same name with Varuna himself, which is untenable, as all such attempts to prove it have failed (cf. Hillebrandt ibid.: 6). Furthermore, the Avestan hypothetical form * Vouruna proposed by her is impossible by any phonetic law (see below). Moreover, the name of the latter, viz. nāpat designates him specifically as "the offspring, viz. son of the Waters", whereas Varuna is "Lord and Overlord of the Waters".

Varuna's connection with ships and ocean is vividly described by the seer Vasiștha, Rig-Veda VII 88:

Verse 3. â yád ruhăva váruṇaśca năvaṃ prá yát samudrámīráyāvamádhyam

ádhi yádapấm snúbhiścárāva prá pren்khá ìnkhayâvahai śubhé kam

(When Varuna and me [sc. Vasiștha] embark together and urge our ship into the midst of the sea/ocean, when we two voyage over the ridges of the waters, we will swing with that swing for beauty [sc. of the verses].)

Verse 4. vásiștham ha váruno nāvyādhād rșim cakāra svápā máhobhị

(Varuna placed Vasiștha on the ship, and skillfully with his might made him a seer.)

After the conversion to Christianity, the Slavic god Velesb often appears disguised under the name of his Christian substitute, viz. St. Nicholas (cf. e.g., Uspenskij, 1982, chapter III Nikola i Volos/Veles; cf. also Katičić 2008: 53). In South Slavic folk tradition, Veles $b$ as Nicholas is invariably associated with the sea and ships as his main domain (just like Vedic god Varuna), e.g., an ancient folk-poem from Boka in Montenegro, titled Car Nebeski kad ženjaše Sunce viz. Wedding of the Sun (Vrčević 1883: 71,72; Nodilo 1886: 216) narrates how the Tsar of Heaven invited all the saints to attend the wedding of his son the Sun, and St. Nicholas/Velesb as the bridesman (viz. the best man): 
Verse 8: ...starog svata svetoga Nikolu (the best man St. Nicholas)

At the bride's house, the gifts were presented to the saints, fitting to their particular divine domains and functions:

Verse 21:... a Nikoli more i brodove (...to Nicholas the sea and the ships).

Another folk-poem titled Najveći grijesi viz. The greatest sins (Karadgitch, 1823, Book I, Poem No. 209) adds more elaborate details on the subject, viz. Thunder-god Peru, who, like Veles, appears in Slavic folk-tradition disguised under the name of his Christian substitute St. Elijah (cf. Katičić 2008: 53, 117, 124, 128, 133, 135, 140, 173), invites Nicholas/Veles $b$ to join him in their common divine function, acting as protagonists of the same divine cause, not as antagonists, analogously as the Vedic pair Indra and Varuna.

Verses 16-20 ...ta ustani Nikola, da idemo u goru, da pravimo korabe, da vozimo dušice, s ovog sveta na onaj.

(...well, get up, Nicholas, that we go into the mountain, that we build the ships, that we carry the souls [of the deceased] from this world to the other).

The last three verses are indicative of his function as King of the netherworld. With regard to the preceding verses, it should be noted that the realm of the dead is called navb in Slavic (the term is related to Sanskrit nauh, nāvah "ship(s)", Latin navis, navigium "ship, vessel") due to an ancient custom of building a funeral pyre on a ship. The burning of the dead among the Slavs in medieval times (analogous to Hindu custom) is attested by the Arabic explorer Ibn Foslan (cf. Leger 1901: 202).

NB. There is no evidence adduced by Ivanov, Toporov, and Katičić that either Vala or Vrrtra were associated with the ocean/sea, ships and whirlpools.

\section{BLACK WOOL (BLACK FLEECE) BENEATH THE WORLD-TREE SACRED TO GOD}

In an attempted reconstruction of authentic Slavic ritual formulas, Katičić (2008, 254) adducing various comparative examples from Lithuanian, Latvian, Belarusian, and Russian folklore, the thunder-god Perkūnas/Perkōns or Perun appears involved in the battle against a serpent or dragon (Slavic parallel of the mythical fight between Vedic Indra against demon Vrtra), extracted presumably a common ancient mythical formulation:

A) Perunъ bьjetь zтьјь (viz. Perun smites a dragon).

B) Perunъ bьjetь čьrtь (viz. Perun smites a devil).

With regard to Katičić's claim that Indra as the name of the thunder-god is not Indo-European (Katičić 2008: 213,214), it should be pointed out that the name "Indra" appears in a sequential relationship with the term bhaga attributively to form a single expression, viz. Indra-bhaga literally "Strong-dealer, i.e. ,Strong-god" ( (cf. Rig-Veda III 30.18, III 36.5, etc.) of which a perfect match in Slavic divine terminology is the name of Jako-bogz, the Vedic term "Indra" having been successfully translated by the Slavic synonymous word expressive of the very essence of its authentic meaning. The Slavic Jako-bog is attested by Orbini: Della religione di questi Anti scriue Geremia Russo ne gli Annali di Moscouia, fra gli altri Dei ...e lo chiamauano Iacobog, cioe Dio forte (Orbini 
1601: 19). In South Slavic folk-poems, Jakobog appears under his cryptic hypocoristic name Jakša < jak(ostan) "strong, powerful” (cf. Nodilo 1885: 84).

On the Vedic version of the myth, Kuiper remarks It has long been recognized by several students of Vedic mythology that the Rigvedic myth of Indra's combat with the dragon Vrtra has no bearing on natural phenomena such as thunderclouds and rain, but represents an Aryan myth of creation ${ }^{3}$...Indra, while slaying the vrtrá- (viz. the power of resistance of the inert Chaos, residing on the primordial hill), at the same time splits the hill (giri-)... and Fire and Water (Agni and Soma) are forced to leave the undifferentiated world of inertia and to join the heavenly gods. Indra further separates Heaven and Earth, by which act a cosmic dualism of upper world (represented by Devas) and nether world (represented by Asuras) is constituted (Kuiper 1960: 218, 219).

Katičić assumes the identity between the dragon/devil and the Slavic god Veles. However, there is no adduced evidence, either by Ivanov, Toporov, or Katičić, of the existence of formula Perun smites the god Veles, as the indisputable proof (instead of mere conjecture), which is to be expected by an objective explorer. There is no necessity for further conjecture, since the Veda has preserved intact the authentic story in its pristine form, viz. after killing of Vrtra, Indra invites Varuna to join him in their common divine function, cf. Rig-Veda X 124.:

Verse 5. niŕmāyā u tyé ásurā abhūvan tvám ca mā varuna kāmáyāse rónéna rājann ánrtạn viviñcán máma rāṣtrásyãdhipatyamehi

(These Asuras [viz. gods endowed with the power of $m \bar{a} y \bar{a}$ "magic" literally "change"] have become devoid of māyā. But thou O, Varuna [viz. an Asura himself] mayst favor me; discerning the Order [rta] from Dis-Order [an-rta], O, King, come over here [sc. from the nether world to the celestial sphere] and be the overlord of my kingdom.)

As Kuiper correctly observed, the demon Vrtra was killed, but Varuna was incorporated among the gods of the upper world viz. celestial sphere (Kuiper 1979: 34), naturally, as the guardian of rta viz. (natural and social) world order.

Kuiper maintains that To Varuna, the ancient god of the waters of Chaos, a new function is now assigned as the guardian of the cosmic law (rtá-)...As a result of this process of differentiation, the undifferentiated Chaos now constitutes itself as a nether world in opposition to the upper world (Kuiper 1960: 219).

Furthermore, it is specified explicitly in verse 7 that Varuna, not Vrrtra, released the Waters:

Verse 7. kavíh kavitvă diví rūpámásajadaprabhūtī váruṇo nirapáh srjat

(The Poet [kavi, sc. Varuna] has put on his form by poetry [kavitvā] in heaven: Varuna without predominance let the waters flow.)

Analysing various Belarus magic spells, Katičić (2008, 137ff, 153ff) equated god Veles with the serpent lying in the nest of black wool (or: on a black fleece) beneath the World-Tree, even though no single spell ever mentioned the name of Veles.

\footnotetext{
3 The same view had been expressed earlier by Bâl Gangâdhar Tilak, a noted Indian scholar, in his book The Arctic Home in the Vedas. Being Also a New Key to the Interpretation of Many Vedic Texts and Legends, published in 1903 (cf. Pleterski 2014: 86, 87).
} 
Veles indeed, like Vedic Varuna, is connected with the World-Tree, but neither as a serpent nor as a dragon. The previously cited folk-poem Najveći grijesi describes this connexion marvellously:

Verses 1-5: Raslo drvo sred raja, plemenita dafina, plemenito rodila, zlatne grane spustila, lišće joj je srebrno (There's a tree in the midst of heaven, the noble daphne, it has brought forth noble fruits, bowing down its golden branches, its leaves are silvery).

Verses 5-11: Pod njom sveta postelja, svakog cveća nastrta, ponajviše bosiljka, $i$ rumene ružice; na njoj svetac počiva, sveti otac Nikola; $k$ njem dolazi Ilija... (Beneath is the holy bedding, made of flowers of all kinds, mostly of sweet basil and red roses; a saint rests on it, the holy father Nicholas; to him comes Elijah; afterwards Elijah/Perun invites Nicholas/Veles to join him, just as Indra invited Varuna above).

Vedic Varuna is depicted almost identically along with the World-Tree, Rig-Veda I 24.:

Verse 7. abudhne rājā varuṇo vanasyordhvạ̣ stūpaṃ dadate pūtadakṣaḥ nīcīnā sthur upari budhna

(In the baseless space, King Varuna keeps raised the stem of the Tree, He [viz. Varuna] of pure rightness, with those [sc. branches] hanging downwards, and root high above.

Verse 8. urụm hí râjā várunaścakâra süryāya pánthāmánvetavā u

(Wide indeed, King Varuna made a pathway for the sun to go after...)

Obviously, the World-Tree is not a concrete earthy tree as it appears to be in the common interpretatio rustica by unlearned village folks, and regrettably by modern scholarly interpreters. This the most ancient of poetic riddles, this Riddle of Riddles, viz. "the Cosmic Tree" stands as the metaphor for the Sürya "Sun" (mentioned explicitly in verse 8). Thus, it makes the solar viz. celestial aspect of both Veles and Varuna absolutely undeniable. It is further confirmed by the Kauśitaki Brāhmana XVIII :

Paragraph 9. yó ásau tápati ...ástam yanta ... sá vā eșo apáh praviśya váruno bhávati

(He who gives heat [viz. the Sun] ... at the setting [sc. in the evening] ... having entered the waters becomes Varuna.)

The (subterranean) waters (of the ocean) is the hiding (viz. resting) place of the rta "Cosmic Order" during night-time.

This can be inferred from the Rig-Veda V 62. devoted to Varuna and Mitra:

Verse 1. rténa rrtám ápihitam dhruvám vām süryasya yátra vimucánty áśvān

(By the order of you two [sc. Mitra and Varuna] the hidden Order [rta] is established there where they unloose Sürya's horses.)

Moreover, Varuna appears as one of 108 holy names of the Sun in the Mahābhārata III 3.24. (On Varuna's solar aspect, cf. also Sutherland 1991: 77; on Veles' solar aspect, cf. Petrović 1999: 446, 449; on Varuna as celestial deity, cf. Kazanas 2001: 259; for more peculiar views on Varuna, e.g., as the evening star, cf. Simson 1997: 1-35; or on Varuna as the constellation Aquarius, cf. Anghelina 2013: 129, 130).

Varuna, like Veles, is also associated with (hairy) bears, in the above mentioned hymn Rig-Veda I 24 immediately after mentioning the World-Tree and the Sun:

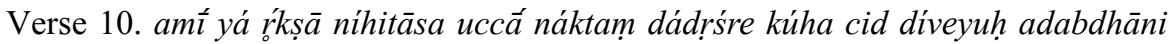
varunasya vratāni 
(Those Bears [R kșāh viz. 7 stars of the constellation Ursa Major] that are placed high to be seen at night, they depart somewhere by day. Undeceived are Varuna's ordinances.)

Naturally, those R Rșāh "Bears" are not wild hirsute beasts (as by interpretatio rustica) but the 7 heavenly rșayah "seers", and are associated with the Krttikās "7 stars of the Pleiades" which were considered the wives of the Bears (Śatapatha Brāhmaṇa II 1.2.4). And again quite expectedly, the Pleiades in Slavic tradition are related to the god Veles whence their name Volosožari, Volosyni, Vlašići, etc. The Russian name [viz. Volosyni] is connected also with the god Volos whose cult became associated with that of a bear in the Northern parts of Russia and in regions near the Volga. The link between the Pleiades and the cult of the bear and/or the Great Bear may be confirmed by the Old Russian text of Afanasiy Nikitin where both the constellation are mentioned together (Ivanov \& Toporov 1973: 25).

In $19^{\text {th }}$-century Serbia, two stars of the Pleiades even bore personal names Vole and Voleta, derived undoubtedly from Volos $b$. Thus, the Vedic parallels indisputably confirm and give posthumous satisfaction to Nodilo's interpretation of Veles (like Varuna) as a solar/celestial divinity (Nodilo 1887: 145), and at the same time discard unjustifiable criticism against his view by Živančević (1963: 54) and by Katičić (2008: 11-35).

Furthermore, the association of Veles with "wool" actually confirms his identity with Vedic sovereign god Varuna himself, namely, the black-coloured ram and "wool" are sacred to Varuna, and there is even specified "the woolly navel of Varuna", Satapatha Brāhmana II 5.2.:

Verse 16. tadyánmeșáśca meși ca bhávatạ̣ eșa vaí pratyákṣaṃ váruṇasya paśuryánmeșastátpratyákṣam varuṇapáśắtprajāḥ prámuñcati

(The reason that there are a ram and a ewe is that the ram is clearly Varuna's victim, so that he thereby sets free the creatures from Varuna's noose.)

and VII 5.2.:

Verse 35. imámūrṇāyumítyūrṇāvalimítyetadváruṇasya năbhimíti vāruṇo hyávistvácam

(Then that of the sheep, This woolen [viz. ürnāyum], 'as they say, or 'this woolly [viz. ürnāvalim], 'as they call it - 'navel [viz. näbhim] of Varuna, 'for the sheep is sacred to Varuna.)

As for the black colour, it is said that krșnam vāso, viz. "a Black Cloth" is the fee to be given for the oblation offered to Varuṇa, since tad(d)hi vārunam yat krṣnam "everything what is Black belongs indeed to Varuṇa" (Śatapatha Brāhmana, V 2.5.17).

Kāthaka Samhitā XIII. 2. states explicitly mrtyur vai varunas "Varuna indeed is death" and "the ram which belongs to Varuna" varunam krṣnam petvam, is equated with pāpman "evil", petva "ram" etad vai pāpmano rūpam "is indeed of evil form", krṣna iva pāpm $\bar{a}$ "for it is Black like Evil". The Vedic demon Vrrtra too (just like Varuna himself) is equated with pāpman viz. "evil, sin, crime, wickedness, evil demon, devil" ( Śatapatha Brāhmaṇa XI 1.5.7).

In Indian mythology, Black is the color of Night, Nirrti [Destruction], of the Manes and of Rain (Hillebrandt ibid.: 15). Kuiper adds that the identification of Varuna with pāpman [Evil] should be noted in the light of the same identification of Nirrti ( Kuiper 1979: 72). Naturally, this is in correlation with Varuna's function as "seizer" and "injurer" who brings destruction to the transgressors of his law. 
To the ancient Aryan mind (Hellenic also, cf. Preller, 1868: 313), the ram represented symbolically the fertilizing rain (assigned to Zeus), naturally, since the curled hairs of the sheep resembles visually the waving (viz. whirling, curly) surface of the flowing water. Moreover, this is how it is further associated (through the medium of water as essential natural liquid element) with the divinities of solemn speech and oaths.

In the view of the Vedic seers (viz. to their ears), the very name Varuna apparently sounded as if related to ürna "wool", which represents the reduced grade (called samprasärana in Sanskrit) of the root var-. Likewise, Slavic Veles (in its Russian variant Volos) is related to Old Slavic $v$ l bna, Russian volna, "wool, but also wave (of water, indicative of this ancient symbolism)" (cf. Pijović 2010: 204).

NB. Ivanov, Toporov and Katičić were not able to adduce any evidence of the association of Vala and Vrtra with wool and the world-tree, since there is apparently no such association in Vedic and Sanskrit sources.

\section{KING OF THE DRAGONS/SERPENTS AND OF THE NETHERWORLD}

Veles is considered the King/Emperor of the netherworld (Ivanov \& Toporov 1973: 16; Katičić 2008: 149) and lord of deceased souls. In some folk tales, Veles is allegedly conceived (though not explicitly specified by name) as "Tsar' Zmiulan (viz. Emperor of the Dragons/Serpents" (Katičić, 2008: 174-175, 227-230), just like Vedic Varuna who is described as rājan viz. a king sitting in his assembly room sabhā, surrounded by many nāgās "dragons" and sarpas "serpents" in the Mahābhārata epic (II 9.8-11). The samudra "ocean/sea" is the home of both Varuna and the nāgās "dragons" (varunasya ca nāgānām alayam. ibid. I 19.5), abounding with huge aquatic creatures makaras "crocodile-like monsters" (ibid. verse 3) and grāhas "seizers" (ibid. verse 4). It is also the abode of subterranean hell known as Pātāla the asylum of the Asuras (ibid., verse 6) and is considered sarva-bhüta-bhayamkara viz. "the terror to all living beings" (ibid. verse 8).

Some critical data on Varuna from the historical point of view are the inscriptions from $11^{\text {th }}$ and $12^{\text {th }} \mathrm{c}$. CE found on the fountain-slabs, called Varuna-deva, in Chamba state, India. ${ }^{5}$

\footnotetext{
4 The Slavic term tsar < Latin Caesar viz. "imperator, emperor" was in fact used for translating the Greek term basileus, viz. "king" in Old Church Slavonic and other medieval Slavic texts. Hence, the Slavic term tsar and the Vedic rājan (etymologically related to the Latin rex "king") are identical in meaning (cf. Katičić 2008: 206).

5 As to the origin [and purpose] of these fountain-slabs, the inscriptions leave no doubt ...that they were designed to secure future bliss of the founder and its relatives, e.g., a deceased wife or husband... The slab itself is invariably designated as a Varuna-deva, i.e., "a god Varuna" for the obvious reason that Varuna, the patron of the waters, is usually carved on it. This name is no longer remembered (Vogel 1911: 33)... Sometimes they [sc. fountain-slabs] are connected with the Nāgās [viz. dragons]... Those at Trilokanāth are locally asserted to have been set up in honor of the Nāga. In epigraphs, however, no mention whatever is made of these demi-gods, so prominent in the popular religion of the Hills. Sometimes these huge stones with their quaint figures and mysterious characters - unintelligible even to the learned Pandit - are looked upon with superstitious dread, and the villagers are often reluctant to give information regarding their whereabouts, for fear that some evil may spring from it (ibid. 34).
} 
The above is undoubtedly related to the Latvian terms Velna Acs literally "the Eye of the demon(onized god) Velns", denoting "the part of a swamp clear from moss and vegetation", and Lithuanian vandens akis “ibid.", literally "water's eye" denoting "wellspring" (Ivanov \& Toporov 1974: 129, 130). There is an analogous toponym in Croatia called Devil's Eye, derived from the name of a well-spring which Katičić relates to Slavic god Veles (Katičić 2012: 59, 60). However, it has nothing to do with Vala or Vrrtra, but with sovereign god Varuna instead, as is perfectly clear from its Indian parallels.

Kuiper opines that the well-spring is the place where Man comes in contact with the nether world and, since Rta [Order] resided in these waters, also with Rta itself(Kuiper 1960: 249).

The Balto-Slavic Velna Acs and Devil's Eye undoubtedly received in antiquity the same level of honor and veneration as the well-springs devoted to Varuṇa and the Nāgās [Dragons], but unlike their Indian parallels, they were not artificially designed with stones and sacred inscriptions, but rather left intact in its natural estate (On the connection of Varuṇa with the Nāgās and serpents, cf. also Eliade 1978: 199-204).

In addition, cf. Atharva-Veda XII. 3. 57, Varuna is closely associated with the $p r d \bar{a} k u$ "a viper, adder, serpent":

Verse 57. pratîcyai tvā diśé váruṇāyắdhipataye pródākave rakṣitré 'nnāyéșumate

(To the western region, to Varuna as Overlord, to Prdāku as Protector...)

The connection between Varuna and the serpents and dragons has been noted by several researchers, e.g., Coomaraswamy enumerated the identifications of Varuna and his realm (viz. Varunaloka) with the $n \bar{a} g \bar{a} s$ and their realm (viz. Nāgaloka) in various Sanskrit texts (Coomaraswamy 1935: 390, 391), which is also corroborated by the findings of the fountain-slabs in Chamba State devoted to both of them. In the abovementioned verse from the Atharva-Veda, Coomaraswamy even equated Varuna directly with the serpent Prdaku. Earlier, Bergaigne identified the sovereign god Varuna with the serpentine demon Vrtra himself (Bergaigne 1883: 147). Based on the references assembled by Coomaraswamy, Eliade had taken virtually the same standpoint: It is to be noted that his [viz. Varuna's] mode of being - terrible sovereign, magician and master of bonds-admits of a surprising closeness to the dragon Vrtra... What is more, Varuna is assimilated to the serpent Ahi and to Vrtra (Eliade 1978: 202-203).

In this connection, Sutherland also maintains: His [sc. Varuna's] punishing, judgmental side is thought to be responsible both for the constriction or "binding" of humans in the bonds (pāśa) of sin and for withholding or "binding" of the waters. In this sense, he has been assimilated to the primordial Vedic asura Vrtra, the supreme serpentine power imprisoning the waters (Sutherland 1991: 77); Their names have a common derivation, from the root vr "to cover, conceal, surround, obstruct" (Sutherland 1991: 181). As regards etymology, it should be emphasized here that the name of the other demon Vala as an appellative designates "enclosure" and is derived from the root val ((Monier-Williams 1899: 927; being a variant of $\boldsymbol{v} \boldsymbol{r}<\boldsymbol{V A R}$ cf. Mayrhofer 1996: 524) of which the Zero Grade would read $v l$, meaning "to cover or enclose or to be covered", being congruous and synonymous with the root $v_{o}$ "to cover, etc." (from which derived both Vrrtra and Varuna). Thus, Hillebrandt's remark It is likely that the designation valá has been 
borrowed from another dialect...(Hillebrandt ibid.: 153) seems well-founded and quite in place. It should be borne in mind that in Vedic language, both Indo-European sounds $\boldsymbol{r}$ and $\boldsymbol{l}$ often merged together into one indistinctive phoneme $\boldsymbol{r}$ (e.g., Latin sol "the sun", but Vedic svar, sūr-ya "the sun").

As for the identity between Varuna and Vrtra, Pleterski also developed a theory that Varuna and Vrtra are one and the same figure, and that the personages can shift or change (cf. Pleterski 2014: 86, 87). ${ }^{6}$

It should be emphasized here again that the demon Vrtra (just like Varuna himself) is equated with pāpman viz. "evil, sin, crime, wickedness, evil demon, devil" (in the Śatapatha Brāhmaṇa XI 1.5.7), thus, it is the Evil, which they share as a common characteristic.

However, Kuiper while objecting to Bergaigne's view, argues: Bergaigne, who rightly stated that there was a mythological relationship between Varuna and Vrtra, was wrong in identifying them directly (Kuiper 1979: 34).

In point of fact, however, Varuna himself is portrayed by the Vedic ritualists not as a serpent or dragon, or any other aquatic or tellurian (viz. theriomorphic) beast or monster, but rather as a man called jumbaká, described in the Taittirīya Brāhmaṇa III 9.3.15, which represents Varuna's true and awe-inspiring formidable form:

Paragraph 15. váruṇo vái jumbakáḥ antatá evá várunam ávayajate khalatér viklidhásya śuklásya pingākṣásya mūrdhán juhoti etád vái váruṇasya rūpám rūpéṇa evá váruṇam ávayajate

That this is not just one of the many images of the god but the true and most essential and awe-inspiring form of Varuna is confirmed by the quotes from other most significant ritual texts, e.g., almost the same phrasing is found in the Śatapatha Brāhmana XIII 3.6.:

Verse 5. váruṇo vaí jumbakáḥ sākṣădeva váruṇamávayajate śuklásya khalatérviklidhasya pingākṣásya mūrdháni juhotyetadvai váruṇasya rūpám rūpéṇaiva váruṇamávayajate

(Varuna verily is Jumbaka in person; he [sacrificer] thus redeems himself from Varuna. He offers it on the head of a white-spotted, baldheaded leprous man [or: old man in bodily decay] with yellow eyes; for that is indeed Varuna's form: by that form he [sc. sacrificer] thus redeems himself from Varuna.) The term viklidha is explained variously as dantara "having oversized teeth, bucktoothed" or as viklinnadeha "old man in bodily decay" (cf. Hillebrandt ibid.: 298; Eggeling 1900: 343).

Moreover, this is corroborated by the Kātyāyana Śrauta Sūtra, which adds that the man representing Varuna in the ritual should receive oblation literally apsu magna viz. "while standing in the water" (Hillebrandt ibid.: 19).

\footnotetext{
${ }_{6}$ Pleterski, argues: Vŗitra obkroža vode, zmaj leži okrog njih, Vŗitra jih je ogradil kot drevo... Če je Vṛitra drevo, to pa postavlja Varuña, če sta oba vladarja istega prostora, če oba nadzorujeta tok vode, je smiselna razlaga da gre za isti lik (Pleterski 2014: 87).
} 
Analogously, Slavic Veles/Volos, like Vedic Varuna, was portrayed rather as a man, sometimes with additional bull horns on his head (but never as a beast), as attested in the records of the destruction of Veles' idols found in Old Russian Chronicles (Leger, 1901: 114, 115; Jakobson ibid.: 34; Katičić, 2008: 124, 129).

As for bald(headed)ness, Katičić (2008: 306) brings a bizarre finding about the inhabitants of place Mošćenice in Istria (above which the mount Perun is located, named after Slavic god of thunder) which still maintain the belief in supernatural powers that operate inside a cave called Potuklica on the near-by river Potok. Reportedly, on the Body Day of Roman-Catholic calendar, the devil (whom Katičić identifies with Veles) takes the gold [which is "yellow", the colour of Veles and Varuna] from inside out to the entrance of the cave in order to dry it up in the sunlight.

There's a story told by the locals how a man went with his son on that day into the cave searching for gold, but suddenly returned from the cave utterly terrified, and even baldheaded. Katičić wonders how that might happen to them when supposedly Veles je zvijer medvjed, kosmat $i$ bradat, pa bi se očekivalo da se vrate potpuno zarasli u dlake (Veles is a beast, a bear, hirsute and bearded, so one would expect them to return from the cave with fully grown hairs and beards). This story and above mentioned Latvian Velna Acs and Lithuanian vandens akis viz. "bald spots in a swamp" are in fact related to the "bald(headed)ness" of Veles (and Varuna alike) and actually testify of the identity between Veles and Varuna, not Veles and Vala, since the Sanskrit appellative valá means only "enclosure, cave, cavern" (Monier-Williams 1899: 927; Hillebrandt, ibid.: 150, 151), and has nothing to do with baldness.

The other Vedic demon, Vrrtra, is not identifiable with Veles either. Maitrāyan̄̄ Samhitā IV 5. states explicitly:

Verse 1. girír vaí virtró (Vrtra indeed is a mountain.)

The Śatapatha Brāhmana repeats three times, cf. III 4.3.13, III 9.4.2 and IV 2.5.15: vrortro vai sóma āsīt tásyaitachárīram yádgiráyo

(Soma, indeed was Vrtra, those mountains [girayah] are his body.)

Katičić apparently has overlooked the identification of Vrtra with the giri "mountain“, when he says: Ali goru na kojoj je ležala zmija Veda ne naziva riječju girih koja je etimološki podudarna sa slavenskim gora..., nego s njom sinonimnom riječi parvatah (But the mount on which the serpent was lying the Veda does not designate by the word 'girih' akin to Slavic 'gora'but by 'parvatah'Katičić 2008: 214).

Katičić as a former pupil of Paul Thieme (to whom he explicitly dedicated the chapter on Veles as Vrtra of his work from 2008: 313, titled "Veles kao Vrtra ispod Plovila kod Novoga Vinodolskog, Dem Andenken an Paul Thieme") has not been able to realize the innate connection of Vrtra and Varuna and to rid himself from the erroneous interpretation of Varuna as "True Speech" developed by his teacher, the theory that has been otherwise demolished by the contributions of many researchers of the Veda from past and present (e.g., Bergaigne, von Bradke, Geldner, Hillebrandt, Coomaraswamy, Eliade, Kuiper, Sutherland, von Simson, Kazanas, Anghelina, etc.). and rejected by most Sanskrit scholars as untenable (e.g., Lommel, Eliade, Kuiper, Sutherland, von Simson, Kazanas, Anghelina, etc.). 
Moreover, quite contrary to Katičić's claim, even in the Vedic hymns the mountain on which the Serpent-Demon Vrtra lied is also designated by the term giri (instead of parvata) within the same context, as in the Rig-Veda IV 17:

Verse 3. bhinád girín śavasā vájram ...vadhīd vrtrám vájreṇa

(Hurling his bolt he [Indra] cleft the mountain [viz. giri]...He [Indra] slaughtered Vrtra with his bolt)

And it appears juxtaposed with parvatam as in VIII 64:

Verse 5. tyám cit párvatạn girín ...vi stotŕbhyo rurojitha

(That hill indeed with rocky heights ...thou [viz. Indra] for thy worshipers brakest through.)

On Vrtra as giri “mountain”, cf. also Dahlaquist 1977: 124; and Kuiper 1960: 218,219, 251.

As Lord of the Netherworld, Varuna is depicted as ruler holding the danda viz. "staff", cf. Manusmrti IX 245: ìso dandasya varuno rājām dandadharo hi sah (Varuna is the lord of punishment, he indeed holds the staff over the kings) just like Yama, another Vedic god of the dead. In the local legends of the city of Dubrovnik, Slavic Veles (under the guise of his Christian substitute St. Blaise, by then called Sv. Vlasi, viz. the honorific plural of Sv. Vlaho as he is called in Dubrovnik, related to the Old Slavic volhvъ "magic" the domain of ancient Veles) appears as a captain, an old man (with grey hair and beard), wielding a staff (just like Varuna) who saves the city with his wise advice to its defenders against the "Smardo-Dassi", viz. "Odorous Spirits" aiming at conquering the city by night. Veles also appears in folk-tales as old wise man called Velimir the Hunter, to be succeeded after his death by the young Veljko Lović (Nodilo 1885: 86-89), of which the name is just a hypocorism of Velimir Lovac (viz. Hunter), the term being actually congruous with and indicative of the function analogous to that of the gods Varuna viz. "seizer, injurer", and Yama synonymous with (the latter is related to Slovenian terms $u$-je-ti "to catch", je-ča "prison", pri-jeti "to hold, catch, grab" (Zero Grade of the root yam-), pri-jem "hold", pri-jemati "to hold, catch, grab"; and Croatian kaj-vernacular jam-iti "to catch, seize, snare, take hold, grab, grasp" (Full Grade of the root yam-).

NB. The justification for this evidence of the function of Veles as a Hunter comes from the analogous example found in Baltic folklore, since his Lithuanian counterpart Velnias figures as a skilful hunter and sharp-sighted teacher of a chase, who is famous for the wild pursuit of game (Jakobson ibid.: 38), which means that this role of his cannot be accidental.

It is said that a deceased soul will see both kings, Yama and god Varuna (Rig-Veda $X$ 14.7) when they go forth on the path of the ancient forefathers, and will rest in a place called gav-yüti viz. "pasture-land [literally "cow-land or cattle-place"] replete with adbhih viz. "waters" (Rig-Veda, ibid. verse 9).

The association of cattle with the realm of the dead coincides with the function of the Slavic god Veles as skotii bog viz. the cattle god. ... the line between 'the god of the cattle' and the realm of the dead may be explained by the common Indo-European concept of the netherworld as a pasture" (Ivanov \& Toporov, 1973: 16). However, it is 
the realm of the god Varuna (and Yama as his double), not of the demon Vala. Furthermore, like Veles, Varuna is conceived as protector of cattle, viz. irya go-pa "a strong cow-herd" (Rig-Veda VIII 41.4). Varuna is also given the epithet vrșabha viz. "bull" (Rig-Veda V 63.3). The variant name of Veles, viz. Russian Volos has been drawn into etymological connection by Gržetić $(1900,31,71)$ with the Slavic word volb viz. "ox, bull”. Analogously, the Lithuanian demon(ized god) Velnias (related to Slavic Veles) is also said to assume the shape of a bull, cattle being protected by him (Jakobson, ibid., 37, 38). Furthermore, Gržetić identifies Slavic Volos with the Avestan gāus-uruuan "soul of the cosmic bull". Significantly, Avestan uruuan viz. "soul/spirit of the dead" has the same meaning as the Lithuanian word vêles viz. "spirits of the dead".

The relationship between the Slavic term Velesz (god) and Lithuanian vêles (spirit/ soul of the dead) matches exactly the Indo-Aryan Vedic and Iranian Avestan pair, viz. Varuna god vs. Uruuan soul/spirit (of the cosmic bull, described in the Yasna 29). The variant name of the Vedic god Varuna attested in the Mitanni-Hittite treaty of $1400 \mathrm{BCE}$ is spelled in the cuneiform syllabic writing as $U-r u-u a-n a$, is congruent with the Iranian form uruuan, and this could hardly have been accidental. Thus, it can be concluded that the Avestan counterpart of Varuna was authentically Uruuan Spirit/Soul (of which Uruua$n a$ is a dual form, coupled with the preceding Mitra), not those "invented" hypothetical names like *Vouruna (proposed by Boyce, ibid.). As for the hypothetical non-existent *Vouruna, the form vouru is attested in Avestan akin to Sanskrit uru "wide" (Mayhofer 1992: 227); hence, it is phonetically incongruent with and impossible to occur in place of the Sanskrit syllable varu; consequently, it cannot represent the Vedic Varuna. As all the prominent Vedic gods, Varuna, viz. Uruuan, quite expectedly, lost his high status during Zarathusta's religious reform, since in the Avesta, the ancient pre-Iranian mythology has gone through an advanced stage of corruption (Hillebrandt ibid.: 112).

The association of Veles and Varuna with the nether world (analogously as the Iranian parallel Uruuan) testify unanimously of their connection with the deceased Souls/Spirits, at least in the mind of the ancient Slavic and Vedic seers, and may well be derived from the root $v r$ "to cover, enclose, bind", since the soul is "covered by the body, enclosed/ imprisoned in the body, or bound/bonded within the body", and is apparently related to Tocharian wal "to die", walu "the dead", the feminine plural (oblique cases) walunt- that coincides with Luwian ulant "ibid." (Ivanov \& Toporov 1973: 22). This is further justified by the Baltic parallels, viz. Lithuanian since Velinas [sc. Velnias] is primarily the god of the dead, and located below the earth; hence the forest pools are said to be his eyes. His name relates directly to the Vẽles, the spirits of the dead (West 2007: 147).

For this reason, both the Aryans and ancient Slavs used to burn their deceased in order to set the soul of the deceased person free from the imprisonment of the body and to send him immediately into paradise.

NB. There is no evidence adduced by Ivanov, Toporov and Katičić that Vrrtra and Vala were considered Kings. 


\section{SWEET BASIL (OCIMIUM BASILICUM)}

As for sweet basil, says Nodilo: Bosiljak, ocimium basilicum ... ima veliku znamenitost sa dvojakog simbolizma: njegov cvijet znači i smrt i ljubav. U Indiji slična bilina, ocimium sanctum, znamenuje isto ovo dvoje ... Što je bosiljkov cvijet sitan i bijel, time označuje boga tvorca, pri sutonu i uranku, a što je miomirisan, dolikuje ljubavi plodnoga boga (Sweet Basil, Ocimiun Basilicum ... The plant is significant due to its two-sided symbolism, viz. its flower means both death and love. In India 'Ocimium sanctum' has the same significance ... Its tiny white flower symbolizes the creator god at dusk and at dawn, while his sweet scent appropriately indicates love and fecundity of the god; Nodilo 1885: 92). Its symbolic value is congruent with the symbolism of god Varuna (and Veles alike), viz. beside his designation as mrtyu "Death" he is also designated as $\bar{a} y u$ "Life", since Varuna is samvatsara "Year", and Life is the Year (Śatapatha Brāhmana IV 1.4.10), for a woman, a cow, or a mare víjāyate samvatsare viz. "bring forth an offspring in a Year's time“ (idem. XI 1.6.2). When invoked alone, Varuna represented to the minds of the Vedic seers the unity of opposites all by himself, i.e., the unified wholeness, the totality, like Prajāpati "Lord of Progeny" (for Prajāpati is the Year, Śatapatha Brāhmana II 2.2.3-5). Significantly, it is stated explicitly about Varuna in the Rig-Veda I 25.:

Verse 8. veda māso dvādaśa...vedā ya upajāyate (he knows 12 months and one being born besides them viz. intercalary one).

The 12 months plus one intercalary month undoubtedly represent the Year. Only when invoked in pairs with Indra or Mitra, does Varuna appear as the embodiment of the opposite dark principle to either of them.

\section{AQUATIC MONSTER GOD'S VEHICLE}

In Hindu iconography, Varuna is coupled with an aquatic monster called makara, which is considered the vehicle of the God. It is depicted with the head and forelegs of an antelope or a goat, and body of a fish or crocodile. It is also called jala-rüpa "water-form". (Dalal 2010: 224).

The term mákara denotes: a kind of sea-monster, sometimes confounded with the crocodile, shark, dolphin, etc. (Monier-Williams 1899: 771).

The Rüpamandana (classic on iconography) describes Varuna the regent of the west as having four arms. In three of his hands, he holds a pāśa (noose), a lotus and a jewel box (lower left hand). Furthermore, his lower right hand is bestowing blessings on the devotee. He is riding a crocodile nakra-arudam (Sreenivasa Rao 2012).

The Silpa-ratna (classic on fine arts) gives a slightly different picture of Varuna, viz. he is wearing yellow garments [the colour of Veles as well]. Varuna holds a noose ( $p \bar{a} s ́ a)$ in each of his two hands and is riding a Makara (Sreenivasa Rao 2012).

The association of the god Varuna (and Veles likewise) with aquatic and tellurian monsters was authentically meant to emphasize his power and control exercised over 
those dreadful creatures in order to serve him as the instruments for maintaining Natural and Social World Order, viz. for punishing the sinners and violators of the law.

There is recorded an analogous belief in pre-Christian Europe among the Mediterranean inhabitants at Malta who regarded the function of the serpents to be the same as that of the gods, viz. as the avengers of sins, e.g., when the apostle Paul landed once on the shore of Malta, the islanders ... built a fire and welcomed us ...Paul gathered a pile of brushwood and, as he put it on the fire, a viper, driven out by the heat, fastened itself on his hand... The islanders concluded that this man must be a murderer; for though he escaped from the sea, the goddess Justice has not allowed him to live (The Holy Bible, Acts, 28:1-6).

\section{CONCLUSION}

After exploring all the existing data, it is difficult to see how it is possible to reconcile all the characteristics of the Slavic god Veles with that of the Vedic demons Vala or Vrtra. In light of the materials presented here from Vedic and Sanskrit sources, only the character of the Vedic sovereign god Varuna appears to be fully congruent with the Slavic god in all his aspects, features and functions.

NB. Even Toporov (1987: 218) later realized his error and changed his mind on the subject, for he wrote: Само имя Варуна исследователи сопоставляли с хеттским морским божеством Аруной [viz. Hittite Aruna], с древнегреческим богом неба Ураном [viz. Ancient Greek Ouranos] наконец, со славянским Волосом (Велесом) [viz. Slavic Volos/Veles] литовским Велнясом [viz. Lithuanian Velnias] и т. д. Поэтому при сохранении ряда неясностей индоевропейские параллели к этому имени несомненны.

\section{APPENDIX: A COMMON ETYMOLOGY OF THE SLAVIC VELESЪ AND VEDIC VARUNA}

The Functions of Varuna and Its Etymology as Explained by Nirukta

The foremost Vedic nairukta (viz. etymologist) and the chief authority on Vedic semantics and etymology [viz. the Nighaṇtu and the Nirukta] Yāska (7.c. BCE) declares it categorically in the Nirukta X 3:

Varuno vrnoti iti satah tasyaiva bhavati (Sanskrit text, Sarup 1963: 173).

(Varuna is so called because he covers " vr"; cf. Sarup, English translation, 1966: 154).

Yāska justifies his standpoint (on the account that Varuna covers the sky with the clouds), citing Rig-Veda V 85.3-4:

nīcīnabārạ̣ varuṇah kavandham pra sasarja rodasī antarikṣam tena viśvasya bhuvanasya rājā yavam na vrșțir vy unatti bhüma (Varuna sent forth the cloud, opening downwards, and created heaven, earth and the intermediate space. With it, the King of the entire Universe moistens earth as rain the barley; cf. Sarup, ibid.). 
Yāska elaborates further his explanation of Varuna (Nirukta XII 23), citing Rig-Veda I 50.6-7 (which is to prove Varuṇa's unquestionable Solar aspect)

yenā pāvaka cakṣasā bhuranyantam janānanu tvạ̣ varuṇa paśyasi vi dyāmeși rajas pṛthvahā mimāno aktubhị paśyañ janmāni sūrya

(The eye with which, O pure Varuna, thou seest the active sacrifice among men, with that thou reachest heaven in various ways, measuring the wide region and days with nights, and seeing many generations, O Sun; cf. Sarup 1966: 191).

However, after taking into consideration kavandham the key term of the stanza, Sarup's translation of the verb vrnoti seems somewhat misleading. Thus, a more detailed clarification is needed in this case.

In clarifying the name Varuna, the Nirukta X 3 refers to the Rig-Veda V 85.3 for clarification: nīcīnabāram várunah kavandham pra sasarja rodasī" "Varuna sent forth the kávandham (variant kábandham) literally "big cask". Yāska explains the kávandham as megham "cloud", and identifies it as: kabandham udakam bhavati "kabandha is water". The commentary on Nirukta further clarifies the term: bandhiranibhrtatve viz. bandhih dhätuh anibhrtatve "the root bandh denotes an unfixed state with an opening below, between heaven and earth in the atmosphere"; (cf. Bhadkamkar 1942:957). However, the prior member $\mathrm{kad}$ (originally the neuter of the interrogative pronoun $\mathrm{ka}$ ) of the compound ka-bandha is defined in the Nighantu 3.6. as kad iti sukhasya viz. "kad means happiness, or literally good axle-hole", whence kabandha originally "good-bond, well-bound" as a designation of cloud, since water is bound within. The verb vrnoti undoubtedly relates to Varuna's function of binding, here the water in the cask (viz. cloud), which he then releases at will (cf. Bhadkamkar 1942: 955-958; Sarup 1963: (Sanskrit text) 17,173-174; Sarup 1966 (English translation) 153,154).

The basic function of Varuna is indicated by the verb bandh "to bind". The verb is applied to the performance of the officiating priest who binds a sacrificial animal for Varuna and loosens what is bound, e.g. paśúm badhnāmi váruṇaya râjiña "I bind this animal for king Varuna"; (cf. Kuiper 1079: 73); baddhám áva syati varunapāśád eváine muñcati "He loosens what is bound; indeed, he releases them from the noose of Varuna" (Taittirīya Samhitạ̄ VI 2.9.1); váruno vâ eșá durvăg ubhayáto baddhó yád ákșạ̣ "The axle which is bound on both sides is Varuna of bad voice (viz. sound)" (Taittirīya Samhitā VI 2.9.1). Varuṇa's bandhá viz. "bond” is also mentioned: râjjño várunasya bandhó 'si só 'múm āmuṣyāyaṇám amúsyāh putrám ánne prāné badhāna "King Varuna's bond thou art, do thou bind a descendant of such a one, the son of a good family in breath and in food" (Atharva-Veda X 5.44). In post-Vedic scriptures the verb bandh is utilized in relation to Varuna's pāśa "noose or fetters" in two verses of the Manusmrti viz. "Law of Manu": sāksye "nrtạn vadan pāśair badhyate vārunair bhṛ́am "He who speaks untruth is firmly bonded by Varuna’s fetters” (Manusmrti VIII 82); varunena yathā pāśair baddha evābhidriśyate tathā pāpān nigrhn̄ìy àd "As one (sc. a liar or sinner) is seen bound with the fetters by Varuna, exactly so let the king punish the wicked" (Manusmrti IX 309). Another aspect of Varuna's function of binding is expressed by the verb muc, muñcati "to be released ( $s c$. from Varuna's fetters)" in the Vedic rites which presupposes one's being already "seized, held, or tied by Varuna" (cf. Kuiper 1979:67ff.). This is a common 
function of both the Vedic god Varuna and Slavic god Velesz as the gods of oaths, contracts and peace agreements, viz. of social "obligations" (or bindings), which additionally and unquestionably strengthens the identity between them.

G. Dumézil accordingly has defined Varuṇa as "the binder” (cf. Dumézil 1988: 95ff).

Besides, the main function of Varuna is frequently expressed by the verb grah (variant grabh) "to seize, grasp, lay hold of, catch, imprison, capture" (analogous to binding), hence the sinners and sick persons alike, are considered Varuṇa-grhita "seized by Varuna" (Kuiper 1979: 73). When the law is violated váruṇo grhṇāti "Varuna seizes" too (Hillebrandt 1929/1980:21), or literally: ánrte khálu vái kriyámāne váruṇo groṇāti literally "Verily, when án-rta (viz. dis-order, in-justice, un-lawfulness) is being done Varuṇa seizes" (Taittirīya Brāhmaṇa I 7.2.6). Even the stationary waters are said to be "seized by Varuna" (Hillebrandt ibid.13). In accordance with his fundamental function, various aquatic creatures called grāha "seizers" (viz. crocodiles, sharks, serpents, alligators, etc.) and makara "crocodile-like monster", along with the nāgās "dragons" and sarpas "serpents" are assigned to Varuna whose abode is said to be the samudra "ocean/ sea". Of the aquatic animals only those called nakra "crocodile" are sacrificed to Varuna (Hillebrandt ibid. 295). In Hindu mythology makara (and sometimes nakra) is considered to be the vehicle on which Varuna rides holding pāśa the "noose" in his hands (cf. Dalal 2010: 224; see also Sreenivasa Rao 2012, part VI, Varuna Iconography). Even makara is the creature with whom god Krșna the "Black one" has identified himself. In this regard compare above the term krșna as Varuna's fundamental designation. There's even more than that, since Varuna like Krṣṇa is also styled hari "golden" (Atharva-Veda V 11.1). Needless to repeat, Black (e.g. Black Wool, etc.) is a special characteristic of the Slavic Velesъ and his Baltic cognates. In this respect compare the Latvian expression melns $k \bar{a}$ velns "black like Velns" (= Vệlns). And zoloto "gold" and zoloti "golden" are the preeminent designations of the Slavic god Velesъ too (Jakobson ibid. 35,38; Katičić 2008: 306). Significantly, Slavic Velesъ is likewise identified with a crocodile, lizard, dragon, serpent, etc. (Katičić ibid. 206, 207, 243-245), in one word, with the creatures which all belong to the class of grāha "seizers".

Besides, the function of seizing or binding performed by Varuna is essentially the same as the role of Slavic Velesъ (like Lithuanian Vélnias) appearing in folk-tales in the role of a wise old hunter called somewhat cryptically Velimir (the assonance with Veless being so obvious) who at dying hands over his secrets to his successor a young hunter called Veljko Lović (Nodilo 1885:86-89) whose first name is actually a hypocoristic from Velimir, whereas his surname Lović is a derivative (viz. patronymic but also diminutive as well, indicative of his youthfulness) from the noun Lovac viz. "Hunter". The stories about Velimir relate to a temporary death of the god and his rebirth in the form of a young hunter.

7 Bhagavad Gītā X 31: jhașānām makaraś ca asmi "Among the aquatics I am makara".

In the Hindu calendar, Makara marks the end of the Winter Solstice (December/January)... it is the birth of time; and the first day of the New Year. Makara is associated with creation-process; thus it symbolizes time and its cyclical nature. Makara is therefore prominently placed in Sun temples (Sreenivasa Rao 2012). 


\section{VARUNA AND YAMA}

This is related further to Yama of whom is said that a deceased soul will see both kings, Yama and god Varuna (Rig-Veda X 14.7) when they go forth on the path of the ancient forefathers (Hillebrandt ibid. 21), and will rest in a place called gáv-yüti viz. "pasture-land [literally "cow-land or cattle-place"] replete with adbhih viz. "waters" (Rig-Veda, ibid. verse 9). In an attempted restoration of a common IE concept of the otherworld as a meadow for the deceased souls, Puhvel brought into connection the Greek Elýsion pedion "meadowy field" and gávyūti "cow-pasture" the realm of the Vedic god Yama, to which he adduced also Old Russian Volosŭ $\left(<*\right.$ Volsŭ or Velsŭ $\left.<* w^{o}{ }_{e} l s^{u} /_{o}^{-}\right)$'cattle-god' whose name he explained to mean literally '(deified) pasture' (Puhvel 1969: 66). But he remained completely silent about the fact that the realm of gávyūti belongs equally to lord Varuna as specified explicitly in the Rig-Vedic stanza X 14.7 quoted above.

Varuna is closest to Yama in the Veda, both wield the danda "staff", both carry in their hands the pāśa "noose" which is the attribute of the night, of the druh (viz. wrong, harm, falsehood), of death (Hillebrandt ibid. 20,21). Semantically, the root grah or grabh (expressive of Varuna's primal function of seizing) is synonymous with the root yam "to hold, keep in, sustain, restrain, curb, subdue, control, etc.". Yamá is the god who presides over the Pitris (viz. deceased ancestors) and rules the spirits of the dead (Monier-Williams 1899: 845, 846). Mallory and Adams treated the root *yem as a far eastern Indo-Iranian-Tocharian isogloss, Sanskrit and Avestan yam "hold, sustain", Tocharian B yäm "achieve, obtain, reach [<* 'come to hold' or the like]" and separate it from *yemos $>$ Sanskrit yamá "twin" related to Latin geminus, and god Yama with a possible Latin cognate of Remus, the brother of Romulus, derived from * yemonos "twin" (Mallory/ Adams 2006: 207, 276, 435). According to Pokorny all these forms are derivatives from Indo-European *iem "halten, zusammenhalten, paaren, bezwingen" including Old Indic Yamá-h "twin, hermaphrodite" = Avestan Yimō (Pokorny/Starostin ibid. 1370). In his role as lord of the dead, it is highly unlikely that Yama authentically meant "twin", but rather the term must have indicated the same function of seizing, binding, enclosing, as Varuna himself. Thus undoubtedly Yama by his very name was authentically intended to personify the main function of Varuna as his mythological double. As for his Avestan counterpart Yima who is considered to be the first man, it has no exegetic value since it contradicts the Vedic evidence (besides, in the Avesta, the ancient pre-Iranian mythology has gone through an advanced stage of corruption as stressed by Hillebrandt ibid. 112). It is said precisely in the Veda that Yama was prathamo martyānām "first of the mortals" (not prathamo janānām "first of the humans") which relates equally to gods, since gods also were considered mortals, e.g. the moon is described as a dying god who is always reborn. On the other hand, Veda never refers to Yama as jana or manusya viz. "man, human" (Hillebrandt ibid. 223). This Vedic concept of the first dying god is confirmed by the stories about Velimir the Hunter who dies at the old age but is succeeded by (viz. reborn as) his young double Veljko Lović (as demonstrated above). 
Varuna and Velesb in the Tradition of the Indo-Aryan PurĀnas

In order to better clarify the historical and doctrinal parallelism between Varuna and Veleş the ancient Indic tradition as preserved in the Purānas offers even more valuable evidence. In the Veda Varuna seems to be subordinated to Indra who was placed above all other gods, but who in turn later became dethroned himself and allowed to occupy inferior position to that of Hari Krș̣a. Buddhist tradition made Indra even a worshipper of Buddha (Hillebrandt 1980/1929: 38) On the other hand, in the Buddhist texts Varuna becomes a Nāgarājā viz. "King of the Dragons" (Hillebrandt 1980/1927: 248) exactly like Slavic Velesъ in Russian folklore under the title "Tsar Zmiulan". But, there are some more striking parallels found in those Purānic texts which glorify Hari Krș̣na. As demonstrated previously above, the terms hari "gold-hued" and krṣna "black" are the personal designations of Varuna, expressing the same mythological concept

In the Purānas (viz. Harivamsa, Viṣnupurāna, Bhāgavatapurāna) there is a story of the thunder-god Indra, styled invariably Parjanya (all three texts verify unanimously the identity of Indra and Parjanya, related to the Slavic Perunb, cf. Ježić 2011: 101), how he was defeated by Hari Krṣnna, who was thus capable of displaying his supremacy over the thunder-god. Since the Hindu god Hari Krṣna shares the same epithets hari and krṣna with the sovereign Vedic god Varuna who lost temporarily his prabhüti viz. "predominance“" (spoken of in Rig-Veda X 124.7) in opposition to Indra ${ }^{8}$, it becomes clear beyond doubt that Hari Krṣṇa impersonates the character of the Vedic god Varuna in this particular story of his clash with Indra, the story actually narrating how did Varuna regain his lost supremacy over Indra. As is self-evident from the perfectly congruent features of Hari Krṣ̣na Varuña and Hari Krṣ̣na himself, all their identical characteristics could not have occurred in the Purānas arbitrarily or accidentally, but were the innate constituent elements of their characters within the same mythological context, viz. their opposition to Indra.

The story of Krṣna's lifting of mount Govardhana in order to protect the cows and the cowherds of Gokula from the lightnings and thunderbolts sent by Indra (being furious because they were invited by Krṣna to worship the mount Govardhana and their own cows as their divinity, instead of Indra himself). Following Ivanov, Toporrov and Katičić and their earlier erroneous identification of the Vedic demon Vala with the Slavic god Velesz, M.Ježić came at a markedly erroneous conclusion: according to him the story does reflect the myth of the struggle between the two main divine contenders in the pre-Vedic myth of Indra/Parjanya and Vala, or the Balto-Slavic myth of Perunz and Volos b/Velesb. As is clearly demonstrated above, it was not Vala but Varuna who temporarily lost his supremacy over the thunder-god Indra, nor Vala ever bore the epithets hari and krșna, which only the sovereign god Varuna shares with Hari Krṣna.

Thus, it is not Vala whom Hari Krș̣na impersonated in the Purāṇas, but the sovereign god Varuna, of whom Hari Krṣ̣na appears to be a double. It is true that "The correlations

\footnotetext{
8 The supersession of Varuna by Indra is delineated in the Rig-Veda IV 42 and X 124; cf. Kuiper's remark on it: "Bergaigne and von Bradke had rightly stressed the antagonism between the two gods [sc. between Indra and Varuṇa]" Kuiper 1979: 22.
} 
in content are strongly corroborated by Indo-European correspondences in expression" (Ježić 2011: 107) but the myth has preserved ancient formulas identifying Hari Kṛṣna, Varuna and Volosb/Velesb (not Veles and Vala) as is perfectly displayed below:

1) Hari Krș̣na Go-pāla (variant Go-vinda) Bhaga-vat

2) Hari Krșna Varuṇa-Asura Go-pā Deva

3) Zoloti Črъ $九$ ъ Volosъ/Velesъ Skotijь Bogъ

Semantically and etymologically all the three formulas are absolutely identical ("Golden Black Cattle-protecting God"), except for the Slavic term skotijb which is fully synonymous with Go-pā/Go-pāla, viz. "cattle-protecting" though not of the same etymology. Note that Krṣ̣na's title Bhaga-vat comprises in itself the term Bhaga identical with Slavic Bogz.

There is only mount Govardhana which resembles Vala, since Vala is identified with mountain in the Rig-Veda VI 39.2: ... pary adrim usra rtadhitibhir rtayug yujānah rujad arugnam vi valasya sānum (...rushing against the rock/mountain [= adri], with the righteous-minded ones, whose yoke is justice, He [sc. Indra] succeeded to break the never-broken ridge of Vala). Moreover, Vala is even in the Rig-Veda X 68.7 specified as parvata "mountain", the term otherwise erroneosly identified by Ivanov, Topotov and Katičić as the etymological source of the Slavic Perunb. These scholars were not able to discern properly the present participle pervant of the IE root * per-vs. IE noun *Perk ${ }^{w} u n o s$ or ${ }^{*} P e r g^{w}$ unos from which actually derived Slavic form (in Slavic the labio-velar appears decomposed and the velar part subject to elision).

Therefore, the only possible identity between mountain Go-vardhana (viz. "cow-increase") is with Vala (who is likewise called go-vapus "shaped like a cow", a term synonymous with), but not with Krș̣na or Slavic Veless, since neither of them has ever been imagined as an unanimated object like mountain. Mount Govardhana an unanimated object appears a tool in hands of the god in order to fulfill his task.

Krṣ̣na used mount Govardhana as a shelter for the cows, though the struggle was not between the mountain and Indra, but between lord Hari Krș̣na impersonating Hari Krṣ̣na Varuṇa (identical with Slavic Velesz) who thus regained his lost supremacy over Indra. The presented parallels between Hari Kṛṣna Varuṇa and Slavic Veleš additionally confirms the identity of the two gods.

There can be no single doubt in their identity. The only problem is to find and decipher a common etymology of the twosome. It is dealt with in the next section devoted solely to.

\section{A Quest for the Common Etymology}

The Baltic viz. Latvian Vẹlns and Lithuanian Vélnias cognates of the Slavic Velesz, closely match in forms the Vedic name Varuna. Since Slavic and Baltic forms are considered cognates, and both Baltic forms comprises $n$-suffix, they have nothing to do with Vala. The Latvian Vêlns and Velna Acs obviously derived from the earlier forms *Velunas and *Veluna Akis due to the reduction of unaccented short vowels, especially $u$ and $i$. This phonetic law is well attested in many IE languages, e.g. French/English table < Latin tabula; French/English able < Latin habilis, etc.; it occurs frequently in Slavic languages too, e.g. Old Slavic bъděti "to watch, stay awake, keep vigil" > modern bdeti, Old Slavic mbněti "to 
think" > modern mneti. It is found operating even in non-IE languages, e.g. in Japanese the short unaccented vowels $u$ and $i$ are by the rule elided in speech (Devidé 1970: 62; 1976: 8).

The Lithuanian Vélnias on the other hand corresponds exactly to the Vedic form varunya "pertaining to Varuṇa" (cf. sárvasmād varunyä̀ "all that comes from Varuna" Śatapatha Brāhmaṇa V 2.5.16). Both Vedic and Lithuanian forms were made on the model of other Vedic divine names featuring the same suffix -ya, e.g. Sür-ya, Parjan-ya, Nāsat-ya, Pūṣar-ya < *Pūṣan-ya, etc.

The older form Vêlinas might have well derived from the original *Vẽlunas, since the vowel $i$ historically often stem from $u$, e.g. Old Latin lubido $>$ Classical Latin libido "desire"; Ancient Greek muthos $>$ Classical mythos $>$ modern Greek pronunciation mithos as in English "myth" etc.

Thus, both Latvian and Lithuanian forms originally must have matched the Vedic Varuna. The problem arises with the Slavic forms of the god's name which seemingly do not match the other three. Even there are attested two different variants of the name viz. Volosb and Veless not only in Old Russian, but also in South Slavic, namely there are two toponyms in Croatia comprising the form Volos instead of usual Veles, one is Voloski kuk viz. "The Hip of Volos" a rock so named at the source of the river Potok in Istria, and within the same area a place called Volosko viz. "The Place of Volos" (Katičić ibid. 306).

R. Jakobson assumed the prototype of the Slavic god's name to be *Vel-sr but this is highly improbable, since both variants Volosb and Veless were authentically three-syllabic forms. Jakobson treated Veless as an archaic Slavic compound: "The same pair of constituents which serve as two autonomous words in Varuna Asura has merged into one compound in the corresponding Slavic name Velesb. As for the Russian doublet Volosb its most probable prototype had been *Vel-sb..." (Jakobson ibid. 43). However, his analysis was fairly inadequate.

As a compound it must have been formed and spelled originally in accord with the Old Slavic phonetic rules, viz. the short vowels $u$ were to be reduced in the prior member of the compound, which would give the $1^{\text {st }}$ variant from PIE *uoluno- $>*$ Volünu $>$ *Volın and the $2^{\text {nd }}$ one from PIE *ueluno- $>* V e l \breve{n} \breve{u}>* V e l b n b$ to which was attached the final member analogous to Indic $a s u(r a)$, viz. from PIE * $H_{1}$ ensus $>$ Proto-Slavic *ęsŭ (=ensu) $>$ Old Slavic *ess and from either PIE * $H_{2} n s u($ ro $)$ or $H_{2}$ onsu(ro) > Proto-Slavic * $q s \breve{u}$ $(=$ onsu $)>$ Old Slavic * $Q s b$. In merging both members into a compound *Volbnb+Qsb and $* V e l b n \_+e s b$ it would give inevitably due to obvious haplology (viz. repetition of syllables with nasals, hence the omission of one of two similar syllables in fluent speech) the forms *Voloss and *Velęss. The presumed Old Slavic forms with nasalized vowels naturally have undergone changes (viz. de-nasalization) in modern vernaculars similar to Old Russian Volos $b$ and Veles $b$ with the additional elision of the final stem-vowel - $b$ (e.g. Old Slavic bogb "god" > bog in modern vernaculars), whence the modern forms Veles and Volos.

The evidence presented is absolutely sufficient to establish an underlying identity between Vedic Varuṇa Asura, Lithuanian Vélnias, Latvian Vệlns, and Slavic Voloş/Velesı, not only in mythological concept but equally by their common etymology. Thus, the Indic and Balto-Slavic forms indisputably represent the ancient common Proto-Indo-European *ueluno- mythologem. 


\section{REFERENCES}

PRIMARY SOURCES

\section{Vedic and Sanskrit}

Atharva-Veda Samhitā (Sanskrit text) Internet: www.titus.uni-frankfurt.de/texte July-August 2018. Kāthaka Samhitā (Sanskrit text) Internet: www.titus.uni-frankfurt.de/texte July-August 2018.

Das Kaushītaki Brāhmaṇa, 1887. (herg. Bruno Lindner), I Text, Hermann Costenoble, Jena.

Mahābhārata with the Commentary of Nīlakantha. 1929-1936. Shankar Narhar Joshi, Chitrashala Press, Sadashiv Peth, Poona Pune.

Maitrāyanī Samhitā (Sanskrit text) Internet: www.titus.uni-frankfurt.de/texte July-August 2018.

Manusmrti (Sanskrit text) Internet: http://hinduonline.co/Scriptures/Smriti/ManuSmriti.html July-August 2018.

The Nighanțu and the Nirukta (Sanskrit text) In: Sarup, Lakshman. (ed.) 1967. The Nighantu and the Nirukta, the Oldest Indian Treatise on Etymology, Philology and Semantics, Sanskrit text. Motilal Banarsidas, Delhi.

Rgvedasamhitā samhitā evam padapātha.1965. The Hymns of the Rig-Veda in the Samhitā and Pāda texts, ed. by Friedrich Max Muller, II Volumes. Chowkhamba Sanskrit Office Series, Varanasi.

Śatapatha Brāhmana (Sanskrit Text) Internet: www.titus.uni-frankfurt.de/texte July-August 2018.

Taittirīya Brāhmana (Sanskrit text) Internet: www.titus.uni-frankfurt.de/texte July-August 2018

Taittirīya Samhitā (Sanskrit Text) Internet: www.titus.uni-frankfurt.de/texte July-August 2018.

\section{Slavic sources}

Karadgitch, Vuk Stephanovitch 1823. Serbische Volkslieder. Breitkopf und Hartel, Leipzig.

Vrčević, Vuk 1883. Tri glavne narodne svečanosti: Božić, krsno ime i svadba. Naklada Knjižare braće Jovanovića. Pančevo.

\section{SECONDARY SOURCES}

Anghelina, Catalin 2013. On the Nature of the Vedic Gods. Sino-Platonic Papers 241, Philadelphia. Bergaigne, Abel 1883. La religion vedique d'apres les hymnes du Rig-Veda. Tome III. F. Vieweg, Paris.

Bhadkamkar, R.G. (ed.). 1942. The Nirukta of Yāska. The Department of Public Instruction, Bombay Boyce, Mary 1975. A History of Zoroastrianism. Vol. I The Early Period. Brill, Leiden.

Coomaraswamy, Ananda Kentish 1935. Angels and Titans, An Essay on Vedic Ontology. Journal of the American Oriental Society, Vol. 35, 373-419.

Dahlaquist, Allan 1977. Megasthenes and Indian Religion: A Study in Motives and Types. Motilal Banarsidas, Delhi.

Dalal, Roshen 2010. The Religions of India. Penguin Books, London.

Devidé, Vladimir. 1970. Japanska haiku poezija i njen kulturnopovijesni okvir. Sveučilišna naklada Liber, Zagreb. 
Devidé, Vladimir. 1976. Japanska haiku poezija i njen kulturnopovijesni okvir. $2^{\text {nd }}$ enlarged edition. Sveučilišna naklada Liber, Zagreb.

Dumézil, Georges. 1988. Mitra - Varuna: An Essey on Two Indo-European Representations of Sovereignity. Yone Books, New York.

Eliade, Mircea 1978. A History of Religious Ideas. Vol. 1. From the Stone Age to the Eleusinian Mysteries. University of Chicago, Chicago.

Fournet, Arnaud 2010. About the Mitanni Aryan Gods. Journal of Indo-European Studies, Vol. 38 , No. $1 \& 2,26-40$.

Gržetić, Nikola 1900. O Vjeri starih Slovjena prema pravjeri Arijaca i Prasemita (Mythologia comparativa Slavorum I). Author's edition. Mostar.

Hillebrandt, Alfred. 1980. Vedic Mythology. Vol. I. Translated from the original German edition of 1927, Breslau. Motilal Banarsidas, New Delhi.

Hillebrandt, Alfred 1980. Vedic Mythology. Vol. II. Translated from the original German edition of 1929, Breslau. Motilal Banarsidas, New Delhi.

The Holy Bible. 1995. Authorized King James Version. International Bible Society. London.

Ivanov, Vjačeslav Vsevolodovič \& Toporov, Vladimir Nikolajevič 1973. A comparative study of the group of Baltic mythological terms from the root *vel-. Baltistica, Vilnius, T.9, Nr. 1: 15-27.

Ivanov, Vjačeslav Vsevolodovič - Toporov, Vladimir Nikolajevič. 1974. Issledovanija v oblasti slavjanskix drevnostej. Leksičeskie I frayeologičeskie voprosy rekonstrukcii tekstov. Nauka, Moscow.

Jakobson, Roman 1969. The Slavic God Veles and His Indo-European Cognates. In: Roman Jakobson Selected Writings. VII Contributions to Comparative Mythology. (ed. by S.Rudy). Mouton, Berlin, 33-48.

Katičić, Radoslav 2008. Bozanski boj. Ibis grafika, Zagreb.

Katičić, Radoslav 2011. Gazdarica na vratima. Ibis grafika, Zagreb.

Katičić, Radoslav 2012. Vražje oko. Studia mythologica Slavica 15, Ljubljana, 59-61.

Kazanas, Nicholas 2001. Indo-European Deities and the Rigveda. Journal of Indo-European Studies, Vol 29, No. 3 \& 4: 257-295.

Kuiper, Franciscus Bernardus Jacobus 1960. The Ancient Aryan Verbal Contest. Indo-Iranian Journal, Leiden, Vol.4, No.4: 217-284.

Kuiper, Franciscus Bernardus Jacobus 1970. Cosmogony and Conception: A Query. History of Religions, Vol 10 (November), 108.

Kuiper, Franciscus Bernardus Jacobus 1979. Varuna and Vidusaka: On the origin of the Sanskrit Drama. North Holland Publishing Company, Amsterdam.

Leger, Louis 1901. La mythologie Slave. Paris. The first Serbian edition, Zadužbina Ilije Kolarca, Belgrade, 1904.

Mayrhofer, Manfred 1992. Etymologische Worterbuch des Altindoarischen, Band I, Carl Winter Universitatsverlag, Heidelberg.

Mayrhofer, Manfred. 1996. Etymologische Worterbuch des Altindoarischen, Band II, Carl Winter Universitatsverlag, Heidelberg.

Ježić, Mislav 2011. Krsṣna diže goru Govardhanu: pobjeđuje li to Veles Peruna u indijskoj predaji? / Kṛṣna lifts up Mount Govardhana: Does Velesъ defeat Perunъ in the indian Purāṇic tradtion? In: Pleterski Andrej, Vinščak, Tomo (eds.), Perunovo koplje. (Studia mythologica Slavica - Supplementa, Supplementum 4), Ljubljana: Založba ZRC, 99-107. 
Mallory, J.P., Adams, D.Q. 2006. The Oxford Introduction to the Proto-Indo-European and the Proto-Indo-European World. Oxford University Press, Oxford.

Monier-Williams 1899. A Sanskrit-English Dictionary. Oxford.

Nodilo, Nadko 1885. Religija Srba i Hrvata. Dio I. Sutvid i Vida. Jugoslavenska Akademija Znanosti i Umjetnosti (JAZU), Rad No. 77, Book XII. Zagreb.

Nodilo, Nadko 1886. Dio III. Sunce. JAZU, Rad No. 81, Book XIV. Zagreb.

Nodilo, Nadko 1887. Dio IV. Sunce dvanaestoliko i gradnja mlade godine. JAZU, Rad No. 84, Book XVI. Zagreb.

Orbini, Mavro. 1601. Il Regno de gli Slavi. Appresso Girolamo Concordia, Pesaro.

Petrović, Sreten 1999. Srpska mitologija. Sistem srpske mitologije. I knjiga. Prosveta, Niš.

Pijović, Marko 2010. Nekoliko misli o mogućem podrijetlu naziva Vlah. Studia mythologica Slavica, 13, Ljubljana, 199-209.

Pleterski, Andrej 2014. Kulturni genom. Studia mythologica Slavica, Supplementa 10, Ljubljana.

Pokorny, Julius, Starostin, George. 2007. Proto-Indo-European Etymological Dictionary. A Revised Edition of Julius Pokorny's Indogermanisches Etymologisches Wörterbuch, Revised and Published by the Dnghu Association. http://dnghu.org

Preller, Ludwig 1868. Griechische Mythologie. II Band. Weidmannsche Buchhandlung, Berlin.

Puhvel, Jaan 1987. Comparative mythology. The John Hopkins University Press, Baltimore.

Sarup, Lakshman (ed.) 1963. The Nighantu and the Nirukta. the Oldest Indian Treatise on Etymology, Philology and Semantics. The Original Text in Sanskrit. Motilal Banarsidas, Delhi.

Sarup, Lakshman (ed.) 1966. The Nighantu and the Nirukta. the Oldest Indian Treatise on Etymology, Philology and Semantics. English translation. Motilal Banarsidas, Delhi.

Sarup, Lakshman (ed.) 1967. The Nighantu and the Nirukta, the Oldest Indian Treatise on Etymology, Philology and Semantics. English translation. Motilal Banarsidas, Delhi.

The Satapatha Brahmana, Part V. 1900. Translated by Julius. Eggeling, Sacred Books of the East, Vol. 44, Oxford.

Simson, Georg von 1997. Zum Ursprung de Gotter Mitra und Varuna, Indo-Iranian Journal, Brill, Leiden, 40(1); 1 - 35.

Skok, Petar 1972. Dictionnaire etymologique de la langue croate ou serbe. Tome II. Academie Yougoslavie des sciences et des beaux-arts, Zagreb.

Sreenivasa Rao 2012. Varuna Iconography. Internet: https://sreenivasaraos.com (02.08.2018).

Sutherland, Gail Hinich 1991. The Disguises of the Demon: The Development of the Yaksa in Hinduism and Buddhism. SUNY Press, New York.

Toporov, Vladimir Nikolajevič. 1987. Varuna. In: Mify narodov mira I. Sovetskaja enciklopedija, Moscow, 217-218.

Uspenskij, Boris Aleksandrovič 1982. Filologičeskie razyskanija v oblasti slavjanskih drevnostej. Relikty jazyčestva v vostočnoslavjanskom kulb te Nikolaja Mirilikijskogo. Chapter III Nikola $i$ Veles. Moscow State University.

Vogel, Jean Philippe 1911. Antiquities of Chamba State. Part I. Inscriptions of the Pre-Muhammadan Period. Archeological Survey of India, Calcutta.

West, Martin Litchfield. 2007. Indo-European Poetry and Myth. Oxford University Press, Oxford.

Živančević, Vladimir 1963. Volos-Veles, Slav Divinity of Theriomorphic Origin. Bulletin de musèe ethnographique de Belgrade, Tome 26, 39-66, Belgrade. 


\section{NOVI UVIDI O STAROSLOVENSKOM BOGU VOLOSU/VELESU IZ VEDSKE PERSPEKTIVE \\ Milorad IVANKOVIĆ \\ $\infty$}

Pri pokušaju rekonstruisanja pretpostavljene središnje teme u okviru drevne slovenske mitologije, t.j. kosmičke bitke izmedju boga gromovnika Peruna i njegova suprotnika skotjega boga Velesa, filolozi Ivanov i Toporov (1973) oslanjajući se na primere iz baltičkog folklora i vedske mitologije, poistovetili su staroslovenskoga boga Velesa sa vedskim demonom Valom. Na istom tragu, njihov sledbenik Katičić (2008) došao je do gotovo istovetnih rezultata samo s tom razlikom što je poistovetio staroslovenskoga boga Velesa sa drugim vedskim demonom Vrrtrom. Nažalost, dokazi sabrani iz izvornih vedskih i sanskrtskih tekstova, te izloženi u ovoj raspravi, pobijaju i opovrgavaju gore pomenuta tumačenja i poistovećivanja, i otkrivaju sasvim drugo lice staroslovenskoga boga Velesa.

Milorad Ivanković, unaffiliated researcher of Sanskrit, Veda and ancient texts and languages; Indology and Sinology, CDK; Omladinski trg 6/4; SRB-26300 Vršac (Verschez), Serbia, a.grnivaso@gmail.com 